\title{
- LAW
}

IRSTI 68.32 .04

https://doi.org/10.26577/CAJSH-2019-3-s5

\section{PROBLEMS OF FORMATION ANTICORRUPTION LEGAL AWARENESS}

\author{
${ }^{1}$ Joshua Castellino, ${ }^{2}$ Mynbatyrova N.K. \\ ${ }^{1}$ Professor of Law, Middlesex University, UK, Middlesex, \\ e-mail: j.castellino@mdx.ac.uk \\ ${ }^{2}$ Candidate of Juridical Sciences, Associate Professor of the Department of Theory and History of State and Law, \\ Constitutional and Administrative Law, Law Faculty, \\ Al-Farabi Kazakh National University, Kazakhstan, Almaty, \\ e-mail: nurlaiym@mail.ru
}

\begin{abstract}
Abctract. The article is consider problem of current corruption and how to deal with it is discussed. At the same time, modern peculiarities of the legal awareness of anti-corruption law are analyzed and studied. The author of the article also pays special attention to the development of legal awareness. The results and conclusions reached by the author can be used to ensure the state policy, increase the legal awareness of the society, and encourage the legal education of the society.

Corruption in all its manifestations represents a serious threat to the national security of any state, has a destabilizing effect on all areas of society and the individual. The key to successfully countering its manifestations is not only the effective operation of state institutions in this area, but also a clear understanding by every citizen of corruption as an absolutely unacceptable social phenomenon. Corruption is a large-scale problem of our time. No state, regardless of its socio-economic and political structure, has absolute immunity to corruption. Today we are talking about the fight against corruption, its development and structure, the world outlook of citizens, and the whole economy. The First President of the Republic of Kazakhstan, the Leader of the Nation Nazarbayev N.A. underlined in his annual Address to the people of Kazakhstan the importance of anti-corruption. Anti-corruption has become one of the priority directions of Kazakhstan's legal reform. At this point, corruption issues are frequently heard in the media and public speeches. Different ways and methods of combating corruption are being developed.

Key words: law, legal interpretation, legal awareness, legal nihilism, the state, the activities of the State, corruption.

$$
\begin{gathered}
{ }^{1} \text { Кастеллино Дж., }{ }^{2} \text { Мынбатырова Н.К., } \\
{ }^{1} \text { профессор, Миддлсекс университеті, Ұлыбритания, Миддлсекс, } \\
\text { e-mail: j.castellino@mdx.ac.uk }
\end{gathered}
$$$$
\text { ²заң ғылымдарының кандидаты, әл-Фараби атындағы ҚазҰУ-дың заң факультеті, }
$$

мемлекет және құқық теориясы мен тарихы, конституциялық және әкімшілік құқығы кафедрасының доценті,

Қазақстан, Алматы қ., e-mail: nurlaiym@mail.ru
\end{abstract}

\section{Сыбайлас жемқорлыққа қарсы құқықтық сананы қалыптастыру мәселесі}

Аңдатпа. Жұмыста қазіргі кездегі сыбайлас жемқорлықтың туындау мәселелері және онымен күресу жолдары мен мазмұндық тұстары ашылып, қарастырылады. Сонымен қатар қазіргі сыбайлас жемқорлыққа қарсы құқықтық сананың ерекшеліктері талданып, жан-жақты зерттелінеді. Сондай-ақ мақаланың авторы құқықтық сананың ары қарай дамуына аса назар бөледі. Автордың қол жеткізген нәтижелері мен қорытындыларын мемлекеттік саясаттың қамтамасыз етілуіне, қоғамның құқықтық санасын арттыруға, қоғамның құқықтық 
тәрбиесін көтермелеу ісінде қолдануға болады. Барлық көріністеріндегі сыбайластық кез келген мемлекеттің ұлттық қауіпсіздігіне елеулі қатер болып табылады, қоғамның және жеке тұлғаның барлық салаларына тұрақсыздандырушы әсер етеді. Өз көріністеріне сәтті қарсы тұрудың кілті тек осы саладағы мемлекеттік мекемелердің тиімді жұмысы ғана емес, сондай-ақ әрбір азаматтың мүлдем қолайсыз әлеуметтік құбылыс ретінде айқын түсінуі болып табылады. Сыбайлас жемқорлық біздің уақытымыздың ауқымды мәселесі болып табылады. Бірде-бір мемлекет, оның әлеуметтік-экономикалық және саяси құрылымына қарамастан, сыбайлас жемқорлыққа мүлдем иммунитет бермейді. Бүгінде біз сыбайлас жемқорлыққа қарсы күрес, оның дамуы мен құрылымы, азаматтардың дүниетанымдық көзқарасы және тұтастай алғанда экономика туралы айтып отырмыз. Қазақстан Республикасының Тұңғыш Президенті, Елбасы Н.Ә. Назарбаев жыл сайынғы Қазақстан халқына Жолдауында жемқорлыққа қарсы маңыздылығын атап өтті. Сыбайлас жемқорлыққа қарсы іс-қимыл Қазақстандағы құқықтық реформалардың басым бағыттарының бірі болды. Бұл кезде бұқаралық ақпарат құралдарында және қоғамдық тыңдауларда сыбайлас жемқорлық мәселелері жиі естіледі. Сыбайлас жемқорлыққа қарсы күрестің әртүрлі тәсілдері мен әдістері әзірленуде.

Түйін сөздер: құқық, құқықтық таным, құқықтық сана, құқықтық нигилизм, мемлекет, мемлекеттің функциясы, сыбайлас жемқорлық.

${ }^{1}$ Кастеллино Дж., ${ }^{2}$ Мынбатырова Н.К.

${ }^{1}$ Профессор, университет Миддлсекс, Великобритания, Миддлсекс, e-mail: j.castellino@mdx.ac.uk

${ }^{2}$ Кандидат юридических наук, доцент кафедры теории и истории государства и права, конституционного и административного права юридического факультета, Казахский национальный университет им. аль-Фараби, Казахстан, г. Алматы, e-mail: nurlaiym@mail.ru

\title{
Проблемы формирования антикоррупционного правосознания
}

\begin{abstract}
Аннотация. В работе рассматриваются содержательные стороны антикоррупционного правосознания, всесторонне исследуются природа возникновения коррупционных правонарушений и пути их устранения. В работе также особое внимание уделяется дальнейшему развитию правосознания общества. Основные выводы и положения авторов могут быть использованы в обеспечении политики государства, в повышении правосознания и правового воспитания казахстанского общества. Коррупция во всех ее проявлениях представляет собой серьезную угрозу национальной безопасности любого государства, оказывает дестабилизирующее воздействие на все сферы жизни общества и отдельных людей. Ключом к успешному противодействию его проявлениям является не только эффективное функционирование государственных институтов в этой области, но и четкое понимание каждым гражданином коррупции как абсолютно неприемлемого социального явления. Коррупция это масштабная проблема нашего времени. Ни одно государство, независимо от его социально-экономической и политической структуры, не обладает абсолютным иммунитетом к коррупции. Сегодня мы говорим о борьбе с коррупцией, ее развитии и структуре, мировоззрении граждан и всей экономики. Первый Президент Республики Казахстан, Лидер Нации Н.А. Назарбаев в своем ежегодном Послании народу Казахстана подчеркивал важность борьбы с коррупцией. Борьба с коррупцией стала одним из приоритетных направлений правовой реформы Казахстана. В этот момент проблемы коррупции часто звучат в СМИ и публичных выступлениях. Разрабатываются разные способы и методы борьбы с коррупцией.

Ключевые слова: право, правопонимание, правовое сознание, правовой нигилизм, государство, деятельность государства, коррупция.
\end{abstract}

Introduction. Corruption in all spheres of society, in particular economy, social sphere, politics, etc. adverse effects. The negative effects of this phenomenon are so serious that it will not only hurt the development of society but also seriously affect the national security of the country.

According to economists, corruption is determined based on the premise that it is rational a type of behavior aimed at finding the best way interests in the context of limited resources. In sociology, corruption is understood as a dysfunctional phenomenon, the pathology of society, generates ugly forms of relationships between people. Sociological approach defines this socio-economic phenomenon as informal system of regulation of public processes existing in parallel with the official mechanism of such regulation and generated ineffective activity of public authorities.

In political science, corruption is considered as one of the phenomena of the political sphere, deforming the political organization of society. Here is a study of corruption mainly associated with the question of the possession of power or a way to fight for it.

Corruption in such a context is understood as behavior that expresses in the illegitimate use by officials of their position for the purpose of occupying and retaining power in society. These corruption re- 
lations themselves, according to political scientists, especially clearly manifested during the election.

Formal legal model of corruption, ignoring economic, political and sociological characteristics of corruption, based on the recognition that corruptionit is a system of unlawful actions of power subjects related to the violation, first of all, special legal norms defining the activities of state bodies and officials. Within the framework of this paradigm, only the act that is in the sphere of legal regulation and may be qualified as an official crime or offense.

Literature review. A cultural-logical approach to the definition of the essence of corruption offers three interpretations this phenomenon. According to the first interpretation, corruption is peculiar culture (business or organizational) and should be analyzed in terms of reproduced within the business community or organization of symbols, myths, customs, ten representations and basic values. According to the second cultural interpretation, corruption is a temporary condition, dysfunction in a culture that becomes possible in a situation of anomie, negative attitudes or indifference of a significant part of communities to social norms generated by the conflict between elements of the system values. For example, anomia occurs when symbols are exalted in society success (for example, material), supposedly common to the entire population as a whole, while how do the current rules and regulations limit or completely eliminate access to legal means of achieving these values for a significant part of the population. Third interpretation within the framework of the cultural approach considers corruption not as temporary, painful condition, but as a phenomenon, constantly reproducible cultural a tradition that relies on permanent, stable features. (Hegel, 1990)

Some academic psychologists see corrupt behavior as dependence, which develops in four steps. The first stage has character one-time remuneration, and at the second stage there is dependence, (a corrupt official is waiting for this event, anticipating a moment of corrupt behavior).

The symptom of the third stage of corruption as an addiction is the appearance of depressive signs with a shift of priority exclusively to corrupt behavior, which turns into a certain dope, allowing you to experience a feeling of comfort, have place resistant frequency, activity in the search for opportunities for corruption behavior and the development of effective corruption schemes. Last fourth stage occurs when a person constantly exists in the stream of corruption income, divorced from reality, losing the feeling of empathy and even the ability to rejoice what gets as a result of corrupt acts.
Material and Methods. Corruption in the global economy: infringes the mechanisms of market competition, leads to the inefficient distribution of state budget funds, unfair distribution of income, promotes rise in prices for goods, creates an organized criminal group and creates shadow economy. All of this impedes the taxation of the state budget and the implementation of the economic activity of the state.

Corruption in the social sphere: It promotes unfair distribution of living things that in turn leads to property inequalities, restricts the right of the state, which regulates the existence of the state and society, and in the consciousness of the society, the views and feelings about the vulnerability of citizens to power and criminality are formed (Vengerov, 2000).

Corruption offenses include bribery, stealing in their favor, misuse of authority, and crimes can be attributed. At present, countering corruption, including bribery is a challenge. The relative vulnerability of the majority of the population to corruption and the tolerance to society have limited opportunities to prevent and combat this crime. For many entrepreneurs, citizens, and other employees, unlawful remuneration for official acts has become a usual and normal phenomenon.

At present, there are two main areas for fighting corruption:

Firstly, the fight against the external appearance of corruption is a direct counteraction to the subjects of corruption, by means of direct influence on the corrupt actors, in order to stop their illicit activities, including legal action, including legal coercion.

It should be borne in mind that corruption is a serious phenomenon, and it is important that the crime is not disclosed. Corruption is often attributed to offenses, which often show the truth and are not interested in punishing the perpetrator. Therefore, there are no opportunities to show corruption elements. It is important to stress that this is a must and should be done to combat corruption offenses. It is important not only to combat corruption, but also to prevent and eliminate corruption (Program, 2014).

The law has established the legal basis of state policy in the fight against corruption, it is aimed at protecting the rights and freedoms of citizens and public interests from threats arising from corruption, ensuring effective activity of state bodies, other organizations, government officials and persons equivalent to them by warning, identify, suppress offenses that create the conditions for corruption and corruption offenses, eliminate their consequences. However, first of all this document is aimed at the prevention and prevention of corruption (Decree, 2006). 
The key measure in the formation of intolerance to corruption among the younger generation is: anti-corruption education, obtaining knowledge in the field of anti-corruption, as well as the practice of application of normative legal acts on countering corruption; anti-corruption outlook - a stable belief system, value orientations, rejection of corruption, which determine student behavior; anti-corruption behavior - actions, actions of a person, motivated by rejection and denial of corruption; prevention of corruption - neutralization of factors of a corruption situation with the help of pedagogical methods and their elimination; as well as information, counseling, advertising.

One of the most important areas of anti-corruption policy is the change in public consciousness under the influence of anti-corruption propaganda, the formation of anti-corruption behavior and a negative attitude towards manifestations of corruption. An atmosphere of intolerance towards corruption must be created in society, and this must be fostered. The most important role in this is given to the mass media.

The media is one of the tools for anti-corruption propaganda. Only in cooperation with the media can we form a full-fledged anti-corruption policy, the conditions for its implementation.

The media themselves in the field of anti-corruption activities may, in particular, the following:

- create a database of publications on corruption;

- to educate citizens about corruption and ways of life without corruption, to organize peculiar actions of refusal from bribes;

- search for and describe the experience of countering corruption in other localities and regions of our country;

- to educate citizens, businessmen and officials about the methods used to successfully counter corruption in other countries;

- all its activities contribute to the expansion of openness of government and business to society.

The most important components of anti-corruption activities, as well as anti-corruption advertising, is to determine their main goals and objectives. The goals of anti-corruption advertising, depending on the information placed in it, are anti-corruption information and the formation of anti-corruption behavior. Anti-corruption information occurs in two forms:

- informing the public about anti-corruption measures in public authorities;

- informing the population about the ways to protect their rights and legitimate interests from corrupt officials in law enforcement and judicial bodies (their location, mechanisms for applying to them, etc.).

Formation of anti-corruption behavior of the pop- ulation, including government (municipal) employees is carried out by informational influence in order to reject corruption behavior (formation of passive anti-corruption behavior) or by helping law enforcement agencies to fight corruption (formation of active anti-corruption behavior). Achieving these goals of anti-corruption advertising can help address the main goal of anti-corruption policy - reducing corruption in society and increasing the effectiveness of anticorruption (Law, 2015).

At the same time, to achieve the main goals of anti-corruption advertising, it is necessary to gradually solve a number of interrelated and interdependent tasks, namely:

a) to draw public attention to the problem of corruption;

b) change the attitude of the population towards it unambiguously to the negative;

c) show possible ways to reduce the level of corruption in the republic;

d) change the behavior patterns of residents when confronted with facts of corruption;

e) to create new behavioral values - the rejection of corruption as a means of solving personal, group or corporate interests. At the same time, it is necessary to agree with domestic experts that any social advertising, including anti-corruption, solves only one specific task facing it.

The specificity of anti-corruption advertising forms specific and its main functions. These functions largely coincide with the functions of social advertising, and reflect the specificity of the advertised object. Such functions of anti-corruption advertising are:

1. Informational. The information function is to inform the public about measures to counter corruption, designating the interests of the state and society.

2. Educational. The educational function of anticorruption advertising involves the formation and adjustment of public consciousness, psychological attitudes and behavioral models of the population (the formation of anti-corruption consciousness, anticorruption outlook and anti-corruption behavior).

3. Educational. The educational function of anti-corruption advertising is aimed at disseminating anti-corruption values, educating the public on anticorruption issues.

4. Economic. The economic function of anti-corruption advertising is that in the future, the advertiser may not so much make a profit as to reduce the economic costs associated with corruption.

Anti-corruption education is a purposeful process of training and education in the interests of the individual, society and the state, based on general educa- 
tional programs developed within the framework of state educational standards and implemented in educational institutions for solving the problems of shaping an anti-corruption worldview, increasing level of legal consciousness and legal culture of students.

Within the framework of the Anti-Corruption Strategy, the education system is also an important component. The issue of anti-corruption education and enlightenment of pupils in an educational institution is rather complicated and requires targeted efforts by specialists and the public in general to solve.

In the content of school education and, in particular, in the educational field "Public Disciplines", great attention is paid to the development of the legal culture of the individual, which is considered as one of the most important conditions for solving the strategic political task - turning Kazakhstan into a modern legal state. Tomorrow the youth will have to occupy responsible posts in the system of state authorities and local self-government, public life and business. For pupils, it is important not only to gain certain knowledge, but also to form a negative attitude towards corruption, gaining practical social skills and communication skills that allow you to avoid corrupt practices.

Against the background of an increasing number of various forms of deviant behavior, corruption is increasingly acquiring features that threaten the national security of the state. At the present stage, human activity aimed at increasing the comfort of its existence is at the same time a source of the formation of negative behavior, striving to acquire benefits through illegal activities. In this regard, the rejection and prevention of corruption ceases to be the lot of only professional professionals and becomes a problem for every person (Petrishin, 2013).

Misunderstanding of the importance of preventing corruption leads to the fact that social injustice increases every year, neglect of the law increases, the ecological situation worsens, etc. Many of the negative phenomena in society are a consequence of corruption.

Modern society places high demands on the professional training of students. Under current conditions, the need for anti-corruption implementation of various types of activities, the individual's understanding of the goals and consequences of their actions for society is relevant. This means that one of the most important goals of the educational process is the formation of future thinking specialists, based on the principle of unconditional non-acceptance of corruption in solving any professional and personal tasks. Consequently, there is a need for the formation of a special type of culture, taking into account the peculiarities of human activity in modern conditions of anti-corruption culture.

It is important not only to limit corruption and the way it acts, but also to investigate and investigate the nature of the problem. In order to prevent this as an anti-corruption effort, students should introduce special discipline in higher education institutions aimed at creating anti-corruption ideas (Law, 2008).

It is worth noting that the Law Faculty of Al-Farabi Kazakh National University started to implement this problem in practice. A new discipline called "Legal basis of anti-corruption" was introduced to the curriculum of the current year or 2017-2018 by the faculty of law faculty of the University as a compulsory subject for all faculties. In the discipline students study and study the concepts, systems, historical and legal aspects of corruption, the nature of emergence, the regulatory framework aimed at counteracting corruption in the RK, ways of overcoming and preventing it. It is a good lesson for students. As mentioned above, corruption is a violation of all spheres of the society, so it is envisaged to study in all faculties.

New educational standards involve the formation of key competencies of students, such as: personal, informational, self-cognitive, subject-specific, and civil law. This program is aimed at the formation of anti-corruption consciousness among pupils through the formation of key competencies that will allow them to socialize adequately in modern society (Matuzov, 2003).

This program focuses pupils on the ethical side of the problem. The problem of moral choice, which should be a psychological neoplasm of a modern school graduate, is the most difficult in teaching practice. To date, legal and organizational measures to counter corruption are already being implemented in the Kazakhstan. However, according to the results of various studies, it is clear that corruption in the Kazakhstan state is becoming one of the global problems, with each year increasing its potential. Corruption as a social and legal negative phenomenon is a threat not only to the economic security of the state, but is also a national problem of all states of the world, since a high level of corruption in any state completely destroys all values and traditions, destroys key concepts of morality, legal foundations and a sense of social justice. According to Kazakhstan and foreign scientists, the causes of corruption are in the legal consciousness of the society itself, since legal culture based on historical development has long been formed in any society. In modern Kazakhstan, the legal consciousness of society is successive, especially the firmly established national traditions of different times are seen. Of course, this 
affects the effectiveness of the implementation of the anti-corruption strategy of the Kazakhstan state. In the current socio-economic situation in our country, the importance of analyzing and restructuring those aspects of education that significantly affect the professional potential of a future university graduate and, consequently, determine the life path, is growing. Today, one of the defining sides of education is the fundamental nature of theoretical and practical training of students, including a developed legal consciousness, which implies readiness for preventive anti-corruption activities. Education problems are closely interrelated with the development trends of Kazakh society, which are aimed at the formation of standards of anti-corruption behavior. These standards should include such requirements that could cultivate in young people the rejection of corruption as negative phenomena in society that are completely incompatible with the values of our state. This will be the most important task of Kazakhstan education, since the level of education of the population, its legal culture is not only the face of our state in the global space, but also a matter of national security (Tapchanian, 1999).

Secondly, prevention of corruption is the formation and implementation of anti-corruption policy as an independent function of the state. The country has adopted an anti-corruption strategy for 2015-2025 and its provisions are being implemented.

To address the challenges of combating corruption, it is necessary to involve all Kazakhstani society in the fight against the dangerous phenomenon, to implement complex, systematic measures and to improve the legal framework for strengthening of legal responsibility.

Recently, the level of corruption in the public service has grown so much that today it has become one of the threats to the national security of the country. The problem of anti-corruption is one of the issues of the scientific community, society and the state. Today, corruption is very important for political scientists, government officials and citizens of the country. In recent years, much attention has been paid to the problem of anti-corruption in the system of public services. Such a focus on the part of the state and the society means that corruption is a decline in the effectiveness of public administration. As a result, economic growth in the country will decline, people's well-being will be weakened, the number of criminal cases will increase (Kurazhenkova, 2015).

Corruption is a complex phenomenon that distorts the political, economic, and social foundations of society. Corruption is an attempt by the offenders, political and administrative civil servants to make their own benefit, which seriously damages the state and society. Today, anti-corruption law, anti-corruption strategy, and various anti-corruption programs are in the country. At present the country needs to join the Association of Civilized States. Despite the huge work done by the state apparatus, civil society and the individual in the field of anti-corruption, the number of corruption increases substantially. Corruption fosters the development of a democratic society. In recent years, corrupt officials in civil service in the country have become transnational. Corruption in public service is not only a result of the public and individual, but also as a result of public servants' reputation. Many of them spend illegal profits through offshore banks or foreign real estate. As a result, foreign law enforcement officials are notified.

As noted above, it is not enough for the state apparatus to carry out anti-corruption measures. There is a question of active involvement of the state and civil society in the political life of the country. Every citizen has a great future in the country's future. Every citizen should know the rules of conduct with civil servants and should not make them incapable of corruption. Implementation of innovative and effective public service delivery will undoubtedly contribute to the reduction of public expenditures, reducing corruption, and increasing public confidence in the government. The state, as the main source of public service, defines ways and means of improving the public service delivery system.

The main task of the modern state is to form a qualitative form of public administration. Its main purpose is, of course, to protect and safeguard the legitimate interests and rights of citizens. As we all know, the efficiency of the public service delivery system to meet the needs of citizens is characterized by two factors: availability and quality of service.

It should be noted that from July to December 2018, the Public Reception Program "Civil Control" on the social order of the Agency for Civil Service Affairs and Anti-Corruption of the Republic of Kazakhstan has been launched at the Al-Farabi Kazakh National University. In this project, the law faculty of the Department of Theory and History of State and Law, Constitutional and Administrative Law of the Faculty of Law of the Al-Farabi Kazakh National University is doing a great job. The goal of the project is to provide comprehensive anti-corruption measures, anti-corruption monitoring and anti-corruption culture in society.

Results and Discussion. Public reception performs the following functions: 
1) Provides consultations on compliance with the requirements of the legislation of the Republic of Kazakhstan within the scope of public service, public services, anti-corruption and the Ethical Code;

2) carries out informational and organizational activity aimed at formation of anti-corruption culture, in particular, organizes informational work and events in mass media on a regular basis. (Ayupova, 1997)

The Public Reception Project «Civil Control» is actively implementing these services today. For example, 10th of November, 2018 Al-Farabi Kazakh National University in the frames of the project "Social Analysis of Corruption Risks in the Control-Supervisory Sector" by the Agency of the Republic of Kazakhstan on Corruption under the Governmental Order of the Republic of Kazakhstan on Corruption and Corruption Proceedings.

During the event, the issues of corruption-related and controllable functions of the state bodies were discussed at the meeting. In addition to the public reception of "Civil Control" Public Association "Young people Resource Center of the Kazakh National University named after al-Farabi" Keremet " Askerov A.A. It has not been forgotten that it is impossible to define the anti-corruption law, to exploit the group, to execute the state functions, to direct them to the merits and to identify the consequences of the use of methods and methods. It is necessary to evaluate the prize and to evaluate corruptive risks.

The participants noted in their speeches found that risk and corruptions could be prevented from establishing the entire frame of mind. However, the installation of similar bands can always lead to risk. The analysis of corruptive risks is foreseen for the long-term debt crisis and its deterioration. In the twelve months of the day, some of the problems that existed in the field were offered and I proposed their decision (Yuldybaev, 2008).

In addition, the participants noted in their speeches wrote that corruption has the right to the excellence, and at one time or another, it is possible to distinguish between corrupt practices. For a definition of the corrupt state of the state, it is impossible to detect a social and economic order in the frames of the state act. Degree corrupt risk can be defined by definition and analysis of the internal and social control, and in the case of execution of the specific full - fledged.

By the way, the law enforcement agencies and advisory bodies on the implementation of the law initiated a roundtable. On the results of the seminarmeeting on the topic: "Results of the analysis of corruption risks in the control and supervision sphere", conducted within the framework of the project Pub- lic reception "Civil control" on social order of the Agency for Civil Service and Anti-Corruption of the Republic of Kazakhstan

The main topic of discussion was the problematic issues of the activity of control and supervisory bodies.

Following the seminar meeting, proposals and recommendations were developed to improve the current legislation:

- Due to the fact that it is not possible to find any information about companies in the system, it is necessary to optimize the system and create integration links for the site;

- for the normal functioning of the entire system of control and supervisory functions, it is necessary to improve the current legislation, in particular, the verification of a small enterprise such as cafes and restaurants to 50 places is regulated by law, below 50 places the sanitary epidemiological station has no right to inspect;

- a large number of orders from the control bodies are carried out in written form, in order to avoid the time and expense required, certain types of instructions must be replaced from the written one to the oral one;

- it is necessary to improve the legislation in the field of carrying out a life threat check, in particular if there is a need to hold accountable for the threat to human health. Unscheduled inspections are replaced for verification; it is proposed to be conducted for those entrepreneurs for whom violated Article 11 of the Business Code.

Corruption, along with moral and moral destruction, hinders realization of the state policy and destroys it. The low quality of public service delivery, the social and psychological situation, the presence of acquaintances and royalty contribute to the growth of corruption.

Corruption will have a negative impact on the development of the economy and social infrastructure as well as the power and governance. As a result of corruption in a significant part of the public service sector, the scope of free mandatory service in education, health care and social welfare is reversed (Report, 2017).

Corruption is a reason to get rid of legal liability for offenses committed by offenders, which in turn creates an escape from punishment and degrading authority of the state, increases public confidence in them, and creates the most dangerous phenomenon or legal negligence.

One of the functions of culture is the implementation of the optimal form of life in society. Therefore, the need for anti-corruption implementation of professional and social activities is updated. 
Anti-corruption culture is a state of personal development, which is characterized by the attitude to the problems of ensuring a reduction in the level of a corrupt situation, both in personal environment and in society. It is also a social process aimed at the realization of such conditions of existence and activity in society, the formation and development of such behavioral stereotypes in which corruption becomes an unacceptable phenomenon. From the psychological and pedagogical point of view, this is an integral personality quality that determines the readiness and focus on the development of the need to acquire special scientific legal knowledge, continuous improvement of skills and abilities to realize the rejection of corruption, the formation of certain competencies (Rafiev, 2015).

Anti-corruption culture is an integral part of the general culture and is of a regulatory nature, aimed at a specific result - the mandatory implementation by the individual of the norms of behavior in society, which, in fact, is a moral position. The lack of anticorruption culture leads to a decrease in the culture of society, a decrease in the level of individual values and distorts the process of professional career.

Of course, state authorities pay close attention to the formation of intolerance to corruption in society, but in educational institutions, in our opinion, this is spontaneous and scattered, manifested in holding one-time events, in various forms-lectures, meetings with law enforcement officials, holding meetings, flash mobs and contests.

Increasing corruption can lead to a socially dangerous object, such as bribery.

1) low level of use of information and communication technologies in the process of receiving public services. While introducing the e-government portal, it is not unusual for the public to use it. Although the people know that there is an electronic government, most of the population can not use it. This, in its turn, leads to the informational and technological illiteracy of the population. At the same time, we must address the problem in rural areas. In many rural areas, there is no Internet connection or not. One aspect of this problem, on the other hand, rural people are often unable to use the computer. (Melnichuk, 2008)

2) It is necessary to improve the regulatory framework regulating public services. One of the actual issues of the law enforcement service is the incomplete implementation of the principle of access to the service.

3) There is a need to use international experience of public service. In foreign countries, various portals and websites operate.
It is important to identify the causes of corruption and to be consistent in its fight against corruption, and to achieve transparency, quality and prompt service, which will contribute to reducing corruption and increasing civic activism.

To carry out anti-corruption activities in the country:

- promotion of legal literacy and legal education of the country;

- It is necessary to identify and investigate the negative factors that influence the development of corruption;

- encourage and increase the anti-corruption culture and legal awareness of the Kazakh society;

- It is necessary to interact with the public authorities in the matter.

The causes of corruption should always be studied and should be constantly monitored, and it would be more effective to find ways to prevent it until it faces the consequences of corruption.

Confident in the authorities, corruption that will undermine the authority will seriously hurt the social, political, economic and legal policies of the public, hindering the interests of the community, the exercise of hatred (Zatsepin, 1991).

The key to overcoming corruption is the formation of anti-corruption consciousness, a high legal culture of citizens and their legitimate behavior. Forming a legal culture based on knowledge and respect for the legislation of the Republic of Kazakhstan, on the correct understanding of its norms, conscientious attitude towards the performance of official duties and civic duty, an anti-corruption consciousness is undoubtedly formed. Here the decisive role belongs to society and its institutions, since it is a question of using different means of influencing the inner world of a person and his actions.

Education in the field of countering corruption should form students' legal awareness and civic ethics, instill anti-corruption standards, and competence in combating corruption at various levels: combating corruption at the first level, i.e. based on the basic vocational education received, and at the second level, while mastering additional professional anti-corruption education programs. This education, as a rule, should be directed at the citizen in order to promote legal consciousness and behavior, as well as training in the recognition of corruption and other actions. The basis of basic anti-corruption education lies in the formation of civil responsibility, an uncompromising attitude towards corruption as a negative social and legal phenomenon. The main task of anti-corruption education is to educate in individuals the fundamen- 
tals of civic ethics and the formation of ideas about social control skills, since historical experience, including that of our country, indicates that the use of public control turned out to be an effective means of combating corruption strategy. Many citizens of our country have their own anti-corruption outlook, but they cannot alone or a small group fight against corruption manifestations, however they already have intolerance to its manifestations and cannot close their eyes to corrupt practices in society, which they happened to witness. In a professional sense, anticorruption education is aimed not only at preventing, but also at actually countering corruption.

Thus, the purpose of this education is to form students' anti-corruption outlook, a firm civic and moral position, as well as possession of sustainable knowledge, skills, skills and competence in the field of combating corruption. In general, in the process of anti-corruption education one should strive to overcome legal nihilism. Anti-corruption education is an integral part of the education process as a whole and involves the use of various forms of interactive work in the educational process, which have a significant impact on the formation of the student's personality. (Golik, 2005)

Conclusion. Today it is possible to see the corrupted organizations that have deep roots today. They encourage citizens and organizations to interact with government agencies to fulfill their rules. In our opinion, there are a number of reasons for corruption in public service, including the complexity of the structures of the government, the lack of internal and external control over the functioning of the state power, unequivocal division of powers, duplication of official duties, lack of mechanisms and legal frameworks for the protection of interests of citizens involved in the work of the authorities or something else (Decree, 2017)

For intensive anti-corruption activities in the country:

- constantly develop mechanisms for interaction with public authorities and law enforcement agencies in the fight against corruption;

- adoption of laws and other administrative measures aimed at inviting citizens to participate actively in anti-corruption actions;
- We believe that it is necessary to introduce anticorruption requirements that set out a single system of prohibitions, restrictions and permits that provide corruption prevention.

Structural analysis of the content of anti-corruption consciousness has shown that this is a complex multi-purpose anti-corruption tool used in modern regional and municipal anti-corruption activities that need a relatively new semantic definition. Taking into account the structural analysis of the content of anticorruption campaign conducted by us, the following definition can be proposed.

Anti-corruption campaigning is the dissemination by the subjects of an anti-corruption policy of anti-corruption information in any way, in any form and with the use of any means against an indefinite number of persons, aimed at forming a stable anticorruption outlook and active anti-corruption behavior in society. Of course, the definition of anticorruption campaign presented by us is not ideal, and other approaches to its formation are possible. However, it seems to us that the proposed definition has a number of obvious advantages over the definitions of anti-corruption campaigning available in legal theory. Firstly, it quite fully describes the circle of subjects vested with the authority to carry out anti-corruption campaigning. Secondly, it indicates the object of anti-corruption agitation - anticorruption information. Thirdly, it defines and fixes the main goals of anti-corruption agitation - the formation of a stable anti-corruption outlook and active anti-corruption behavior. Fourthly, it indicates subjects of anti-corruption agitation - an indefinite circle of persons, which does not exclude the use of anti-corruption agitation means and target groups. Fifth, the use of any anti-corruption information methods, forms and means is allowed to achieve the goals of anti-corruption agitation. Sixth, the use of the single legal definition of "anti-corruption agitation" proposed by us allows us to eliminate the legislative contradictions in the implementation of regional and municipal legislative activities in the sphere of combating corruption and thereby improving its quality.

\section{References}

Ayupova Z.K., Sabikenov S.N. (1997) The concept of the rule of law. - Almaty Gylym. -80 p.

Decree of the President of the Republic of Kazakhstan dated July 25, 2006 No. 154 "On the Concept of the Development of Civil Society in the Republic of Kazakhstan for 2006-2011" / Site: // http://online.zakon.kz/document/?doc_id=30014253\&doc i

Decree No. 500 of the President of the Republic of Kazakhstan of June 20, 2017 "On the Approval of the Concept of State Policy in the Religious Sphere of the Republic of Kazakhstan for 2017-2020" / Site: // http://online.zakon.kz/Document/?doc_id=36541164

Golik Yu.V., Karasev V.I. (2005) Corruption as a mechanism of social degradation. - SPb .: Legal Center Press.. - 329 p. 
Hegel. Philosophy of law. Academy of Sciences of the USSR. Institute of Philosophy. From the "Thought". Moscow - 1990 with. - p. 247

Kurazhenkova N.S. (2015) Family as the main institute of education // Internet-journal "The World of Science". - №3 //http:// mir-nauki.com/PDF

Law of the Republic of Kazakhstan dated November 18, 2015 No. 410-V "On Combating Corruption" (with amendments and additions as of July 3, 2017)//http://online.zakon.kz/document/?doc_id=33478302

Law of the Republic of Kazakhstan as of October 20, 2008 No. 70-IV "On the Assembly of the People of Kazakhstan" (with amendments and additions as of July 11, 2017) / Site: // http://online.zakon.kz/Document/?doc_id=30352401 \# pos =0; 0

Matuzov N.I. (2003) Legal awareness and legal culture // Matuzov NI, Malko AV Theory of State and Law: Textbook. - 2nd., Pererab. and additional. - M.: Lawyer, -776 p.

Melnichuk O. (2008) Law and the State in the Concept of Legal Jurisprudence Ilyin. // Monograph: Phoenix,. - 178 p.

National report on combating corruption (Astana, 2017) //http://kyzmet.gov.kz/en/pages/nacionalnyy-doklad-o-protivodeystviikorrupcii

Petrishin O.A. (2013) Civil society is the basis for the formation of legal consciousness in Ukraine. // Bulletin of the Academy of Sciences of Ukraine. - No. 3 (34). - P. 142-161.

Rafiev R.B. (2015) The Role of Civil Society in Counteracting Corruption // The Young Scientist. № 22. - P. 467-469. - URL https://moluch.ru/archive/102/23055

Tapchanian N. (1999) Legal awareness and legal culture of the individual in the conditions of modern Russia: Author's abstract. dis. ... Candidate of Sciences/-M., $-41 \mathrm{p}$.

The Nur Otan party's anti-corruption program for 2015-2025 (approved by the resolution of the Political Council of the Nur Otan Party of November 11, 2014 No. 1) / Site: // http://old.nurotan.kz/en/programma-protivodeystviya- korrupcii-partii-nur-otan-na2015-2025-gody

Vengerov A.B. (2000) Theory of State and Law: A Textbook for Law Schools. 3rd ed. - M .: Jurisprudence. - 528 p.

Zatsepin V.I., Bereshchenko AV, Buchinskaya LM (1991) Young family. Kiev Ukraine. -320 pp.

Yuldybaev B.R. (2008) On Some Aspects of the Formation of a Culture of Family Relations in Modern Russian Society - Bulletin of the Bashkir University. - T. 13. -№ 3 - P. 648-650. 